\title{
Kantian Ethics, Animals, and the Law
}

\section{Citation}

Korsgaard, Christine M. 2013. Kantian Ethics, Animals, and the Law. Oxford Journal of Legal Studies 33, no. 4: 629-648.

\section{Published Version}

doi:10.1093/ojls/gqt028

\section{Permanent link}

http://nrs.harvard.edu/urn-3:HUL.InstRepos:12220746

\section{Terms of Use}

This article was downloaded from Harvard University's DASH repository, and is made available under the terms and conditions applicable to Open Access Policy Articles, as set forth at http:// nrs.harvard.edu/urn-3:HUL.InstRepos:dash.current.terms-of-use\#OAP

\section{Share Your Story}

The Harvard community has made this article openly available.

Please share how this access benefits you. Submit a story.

\section{Accessibility}




\author{
Kantian Ethics, Animals, and the Law \\ Christine M. Korsgaard \\ The Hart Lecture \\ Oxford: May 8, 2012
}

\title{
1. The Legal Bifurcation
}

Following the tradition of Roman law, legal systems divide the world into persons and property, treating human beings as persons, and pretty much everything else, including non-human animals, as property. Persons are the subjects of both rights and obligations, including the right to own property, while objects of property, being by their very nature for the use of persons, have no rights at all. Call that the legal bifurcation. It leaves nonhuman animals in an awkward position. Animals, or at least many of them, are sentient beings with lives of their own and capacities for enjoyment and suffering that seem to make some sort of claim on us. Some have sophisticated cognitive capacities, including some sense of self. But because animals are classified as property, efforts to secure them some legal protections have been of mixed success and have introduced a certain level of incoherence into the laws. In the face of this, some animal rights advocates have suggested that all cognitively sophisticated animals, or all animals generally, ought to be categorized as legal persons.

I wish to ask instead whether we should accept the legal bifurcation. It seems like simple common sense to suppose that non-human animals fall into a different normative category than either people or inanimate objects. But trying to make a case for such a category, and tracing out its moral and legal implications, raises some important 
philosophical questions - questions about where our normative categories come from and how they are related to the natural categories that we use in thinking about the world in ordinary theoretical or scientific terms. These are the questions I explore in this paper. I argue that implicit in Immanuel Kant's moral and political philosophy is a distinctive view about how we establish normative categories and determine which things fall under them. That view is that in order to act rationally, we need to regard ourselves as falling under certain normative categories, and in particular, that we must claim a certain kind of normative standing for ourselves. I also argue that so far as the other animals are concerned, the implications of his view are not exactly what Kant took them to be. The same facts that make it necessary for us to lay claim to both moral and legal personhood also make it necessary for us to claim a separate kind of normative standing for our animal nature as well. The existence of this separate form of standing provides grounds for a challenge to the legal bifurcation and for the idea of animal rights.

\section{Normative and Natural Categories: The Problem of Bridge-Claims}

We might have thought that we could look to Kant for a philosophical justification of the legal bifurcation, since, as I am about to explain, he uses these categories himself. But actually, that would be somewhat backwards, because Kant, in constructing the 
categories that he uses to talk about matters of morality and legal right, was consciously following the tradition of Roman law. ${ }^{1}$

In Section Two of the Groundwork, Kant divides the moral world into persons and things (G 4:428; see also ANTH 7:127). ${ }^{2},{ }^{3}$ A person is an end in herself, who should

\footnotetext{
${ }^{1}$ For an account of Kant's attitude towards and use of Roman law, see John Ladd's introduction to his translation of the first part of Kant's Metaphysics of Morals, The Metaphysical Elements of Justice (Indianapolis: Hackett Publishing Company, $2^{\text {nd }}$ edition, 1999) xxiiff. Since Kant believed that morality is grounded in practical reason, he supposed that true moral ideas would be found embodied, if imperfectly, in actual human intellectual and normative systems, and he vindicates his account of morality in part by showing how this is so. So, for example, in Religion within the Boundaries of Mere Reason (trans. George di Giovanni in the Cambridge Texts in the History of Philosophy series. Cambridge: Cambridge University Press, 1998), Kant seeks to explicate the rational and moral core of such Christian notions as grace, salvation, redemption, and so on. In his political and legal philosophy, he does something similar with the concepts of Roman law. ${ }^{2}$ Personen and Sachen. I have cited Kant's works in the standard way, by the volume and page number of the standard German edition, Kants Gesammelte Schriften (edited by the Royal Prussian (later German) Academy of Sciences (Berlin: George Reimer, later Walter de Gruyter \& Co., 1900--)), which are found in the margins of most translations. The Critique of Pure Reason, however, is cited in its own standard way, by the page numbers of both the first (A) and (B) editions. The translations I have used are:
} ANTH = Anthropology from a Pragmatic Point of View, trans. Mary Gregor. The Hague: Martinus Nijhoff, 1974.

C2 = Critique of Practical Reason, trans. Mary Gregor, in the Cambridge Texts in the History of Philosophy series. Cambridge: Cambridge University Press, 1997.

$\mathrm{C} 1=$ Critique of Pure Reason, trans. Norman Kemp Smith. New York: Macmillan, St. Martin's Press, 1965.

$\mathrm{G}=$ Groundwork of the Metaphysics of Morals, trans. Mary Gregor, in the Cambridge Texts in the History of Philosophy series. Cambridge: Cambridge University Press, 1998. 
Kantian Ethics, Animals, and the Law

Christine M. Korsgaard

p. 4

be valued for her own sake, as an object of respect, and never used as a mere means to some other person's ends. Later we learn this implies that persons are to be regarded as citizens in what Kant calls the Kingdom of Ends, capable of making laws for all rational beings through our choices. A thing, from a practical point of view, is an instrument, which has at most a derivative value as a means, and can be used however we please. As an end in himself, a person has an inner worth or dignity, while a thing, by contrast, has only a price (G 4:435). These ideas are introduced in the course of the argument that leads to the Formula of Humanity, the formulation of the categorical imperative that tells us always to treat humanity as an end in itself. Kant first establishes that if there is a categorical imperative, there must also be, as he says, 'something the existence of which in itself has an absolute worth, something which as an end in itself could be a ground of determinate laws' (G 4:428). He then proceeds to consider various candidates for the end in itself, and at one point he says:

LE $=$ Lectures on Ethics, trans. Peter Heath, New York: Cambridge University Press, 1997. These are actually students' notes from Kant's ethics courses. $\mathrm{MM}=$ The Metaphysics of Morals, trans. Mary Gregor, in the Cambridge Texts in the History of Philosophy series. Cambridge: Cambridge University Press, 1996.

${ }^{3}$ The division of the world into persons and things is especially troublesome because the entities that give rise to some of the most vexing ethical and legal problems are exactly the ones that do not seem to fit comfortably into either category: not only non-human animals, but embryos and fetuses, cultural and artistic treasures, ecosystems and perhaps the environment. None of these are entities to which we could plausibly assign both rights and obligations; but all of them are entities that we are reluctant to regard merely as means, at least if that is taken to imply that we can use them in whatever way we like. In this paper, I consider only the status of non-human animals. 
Kantian Ethics, Animals, and the Law

Christine M. Korsgaard

p. 5

Beings the existence of which rests not on our will but on nature, if they are beings without reason, still have only a relative worth, as means, and are therefore called things, whereas rational beings are called persons because their nature already marks them out as an end in itself, that is, as something that may not be used merely as a means. (G 4:428)

Animals, since they lack reason, are not persons, and therefore are categorized as things. And although in some places Kant spells out humanitarian rules governing the way we should treat the other animals that seem rather advanced for his day, in other places Kant does not hesitate to draw the implications of their categorization as things. ${ }^{4}$ In his book Anthropology, for example, Kant claims that a person is 'a being altogether different in rank and dignity from things, such as irrational animals, which we can dispose of as we please.' (ANTH 8:127).

\footnotetext{
${ }^{4}$ Kant thinks animals should not be hurt or killed unnecessarily, and certainly not for sport (LE 27:460). If they must be killed, it should be quickly and without pain (MM 6:443). We should never perform painful experiments on them for merely speculative purposes, or if there is any other way to achieve the purpose of the experiment (MM 6:443). We should not require harder work of them than we would require of ourselves (MM 6:443). When they do work for us we should we regard them 'just as if' they were members of household (MM 6:443), and when they no longer can work for us, they are entitled to a comfortable retirement at our expense (LE 27:459). Non-human animals, according to Kant, are the proper objects of love, gratitude, and compassion, and failing to treat animals in accordance with these attitudes is 'demeaning to ourselves' (MM 6:443; LE 27:710). Notoriously, however, Kant thinks we owe all of these duties not directly to the animals but rather to ourselves (MM 6:442; LE 27:459).
} 
But what is the basis of these claims? As some people read this argument, when Kant says our nature 'marks us out' as ends, he is making the essentially metaphysical claim that human beings just have a certain form of value. According to this interpretation, rationality or autonomy is a property that confers a kind of intrinsic value on the beings who have it, and therefore they are to be respected and treated in certain ways. Lacking rationality or autonomy, the other animals lack this kind of intrinsic value.

There are several problems with understanding Kant's argument in this way. One is that it does not by itself explain the particular kind of value that rational beings are supposed to have. 'Value' is not a univocal notion - different things are valued in different ways. The kind of value that Kant thinks attaches to 'persons' is one in response to which we are supposed to respect their choices, both in the sense that we leave people free to determine their own course of life and action without interference, and in the sense that we are to regard their chosen ends as things that are good and worthy of pursuit. This is made clear by the nature of the duties that Kant thinks follow from the injunction to respect persons as ends in themselves (G 4:429-31). According to Kant, we are obligated not to usurp other people's control over their own actions by forcing or tricking them into doing what we want or think would be best. In other words, we are not allowed to use other people as mere means to the ends we would choose. Kant also thinks we have a duty to promote the ends of others. To be a moral person, for Kant, is to be a legislator in the Kingdom of Ends, with the right to legislate for everyone through our choices, and 
the correlative obligation to make only those choices by which our fellow citizens could reasonably agree to hold themselves bound. A person could certainly have some kinds of value - even some kinds of value as an end - without it following that his choices ought to be respected and regarded as laws. A prince, or someone held by some religious tradition to be the embodiment of their god, might be valued in the way a precious object is valued - preserved and protected and cherished - without ever being allowed to do anything that he chooses. ${ }^{5},{ }^{6},{ }^{7}$

${ }^{5}$ Of course one might respond that the fact that it is reason that supposedly gives us this value suggests that the appropriate way to respond to the value must have something to do with the operations of a person's reason. But this does not make it obvious that what the value of persons calls for is allowing people to choose their own actions unhindered by coercion or deception, or helping them to promote their chosen ends. Perhaps what is called for is setting people logical and mathematical problems, or even setting up practical obstacles to make sure that they stay rationally active and fit. More needs to be said than just that a certain property has, or gives its possessors, value.

${ }^{6}$ I have come to think that Kant himself, when spelling out the implications of the view that people are ends in themselves, had some tendency to appeal to two quite different ideas of what it means to value people in virtue of our rationality. One of these involves treating rationality as a valuable property, while the other involves treating it as the basis of a normative standing, the standing of a legislator in the Kingdom of Ends. See my 'Valuing our Humanity,' published in Spanish translation by Dulce María Grande in Signos Filosoficos, July-December 2011 and available in English on my website at http://www.people.fas.harvard.edu/ korsgaar/CMK.Valuing.Our.Humanity.pdf .

${ }^{7}$ According to what T. M. Scanlon calls a buck-passing theory of goodness (What We Owe to Each Other (Cambridge, MA: Harvard University Press, 1998, 95-100), for something to be valuable or good is just for us to have reasons to respond to or behave towards it in a certain way. This theory might seem to avoid the problem I have just described: when we say that people are 
But the more important problem is that the proposed claim about the intrinsic value of rational beings is exactly the sort of metaphysical claim whose pretensions Kant's philosophy is designed to debunk. Not being a claim we can make on the basis of scientific evidence, it takes us beyond the limits of experience. Kant does not believe that human beings have the kind of direct rational insight into the nature of things that could tell us that certain entities or objects simply have, as a kind of metaphysical property, intrinsic value.

But the problem in question is not just one for Kant. It is a problem for anyone who claims that in virtue of having certain natural properties - reason, selfconsciousness, sentience, or what have you - a being has 'moral standing.' Kant thinks it is in virtue of having reason that human beings count as persons and so should be valued as ends in themselves. But we may ask how the connection is supposed to be made between having the factual attribute of reason and being a person in the normative sense of 'person' - that is, having certain rights and obligations.

As John Locke famously said, the concept of a person is a 'Forensick' one, applicable only to beings who are capable of taking responsibility for their actions and

valuable, our claim is based on the existence of certain reasons, and the content of those reasons determines what kind of value is in question, so the claim more or less means that we have reason to respect their choices and promote their ends. I believe this just postpones the problem to the question why we have those reasons, or perhaps - if one can say nothing about why reasons exist - then to why we believe that we have them. 
Kantian Ethics, Animals, and the Law

Christine M. Korsgaard

p. 9

conforming to laws. ${ }^{8}$ But if 'persons' necessarily have rights and obligations, it follows that any entity that is to count as a person must have certain natural capacities. Of course depending on their theories of rights and obligations, philosophers will disagree about which natural capacities are required. I myself think it is plausible to say that we cannot intelligibly assign obligations to an entity which is incapable of reaching conclusions about what it ought to do, and acting on those conclusions. ${ }^{9}{ }^{10},{ }^{11}$ And I follow Kant in

\footnotetext{
${ }^{8}$ John Locke, An Essay Concerning Human Understanding (ed. P. H. Nidditch. Oxford: Clarendon Press, 1975) §26, 346.

${ }^{9}$ The statement in the text is slightly oversimplified: it is not merely that the entity who is to count as a person must be capable of acting on its conclusions, but rather that it must be such that it does act on those conclusions unless something is wrong with it. Acting on its conclusions about what it ought to do must be part of its ordinary functioning.

${ }^{10}$ Philosophers in the sentimentalist tradition would deny this. Hume, for example, recognizes a category of what he calls 'natural' virtues, which may be exercised without reference to any thoughts about duty. The benevolent person, as Hume conceives him, helps others because he wants to, not because he thinks he ought to. On Hume's conception, when we say that people have an obligation to be benevolent, we mean only that we would disapprove of them if they were not. Of course there are still some capacities we must attribute to the subjects of these obligations - the ability to recognize the good of others and be motivated by it, for instance - but the capacity to entertain thoughts or draw conclusions about what he ought to do need not be among them. For more specific references to Hume and an analysis of the issues this raises, see my 'Natural Motives and the Motive of Duty: Hume and Kant on Our Duties to Others' (Contemporary Readings in Law and Social Justice, 1(2), 2009: 9-36).

${ }^{11}$ I have characterized the relevant capacities in non-psychological terms because I believe that there can be collective agents, and that this does not require a collective psychology. What it requires is a procedure for making decisions that are authoritative for the group and a natural mechanism for carrying out those decisions that will work unless something goes wrong. Political
} 
thinking that in living beings, the psychological capacities that make that possible are the ones in virtue of which we can be said to have reason. An argument to that effect would show us why having reason is a necessary condition of being a moral person (in the sense of someone with rights and obligations, on analogy with 'legal person,' not in the sense of someone who is morally good). It shows us why having reasons is a necessary condition of being a moral person, but it does show us why it is a sufficient one.

When we ask how we could arrive at this further conclusion, however, a problem arises. I have been assuming all along that we do our theoretical and scientific thinking in terms of a set of what we might call naturalistic concepts, the concept of a human being, the concept of an animal, and the concept of an inanimate object among them. ${ }^{12}$ When I say these concepts are naturalistic, I mean that we learn from experience that there are things that conform to these concepts and so should be categorized accordingly, or at least that the identification of something as fitting under such a concept is an empirical matter. But we do our moral and legal thinking in terms of another set of concepts, normative concepts, which do not seem tied to experience in the same way, and which are so called because they have normative implications, such as Kant's concepts of

states are collective agents in this sense, and that is why they require legislative and executive authorities.

${ }^{12}$ My description of this problem is a little oversimplified. One thing that makes that true is that the concept of an object itself is more a metaphysical one than a scientific one. Another complication is raised by the question whether we can understand what a plant or an animal is without invoking a notion of 'functioning' in a certain way that already has a normative dimension. I set aside these complications here. 
person and thing. That suggests we can arrive at conclusions about how some entity ought to be treated by determining into which of these normative categories it falls. ${ }^{13}$ Debates about whether or when fetuses or non-human animals count as persons, for example, take this form.

That means that there should be what we might think of as 'bridge-claims' announcing our conclusions about which natural objects fall under which normative categories. For instance, we might claim that, absent any special reason why not, every human being is to be treated as a moral person, that is, is to be accorded certain rights and obligations. That would be a bridge-claim linking the naturalistic concept of a human being to the normative concept of a person.

But in saying every that human being 'is to be treated' as a person, as I did just now, I have left my formulation of the bridge-claim deliberately ambiguous, because that is where the problem lies. The problem concerns the status of the bridge claims themselves. Are they factual claims? Or are they moral or normative claims? Should we say, that is, 'every human being is in fact a moral person'? Or 'every human being ought to be treated as a moral person'? There is trouble either way.

\footnotetext{
${ }^{13}$ In the case of some normative concepts, the naturalistically described objects that we categorize under them are not ones whose existence we discover, but rather ones whose existence we know, in a naturalistic way, that we can construct. For instance, we might decide that 'the president' (someone with certain rights and obligations) should be the person who gets the most votes in an election. Obviously, we don't empirically discover that there are people who already fit that description. Instead, we know empirically that we can run an election that will allow us to identify in a factual way who got the most votes.
} 
If we say, 'every human being is in fact a moral person,' then we appear to be arguing from an 'is' to an 'ought,' in violation of the thesis, endorsed by Hume and Kant and many others, that natural facts by themselves do not have normative implications. ${ }^{14}$ On the other hand, if we take the bridge-claims to be normative or moral claims, then we seem to have abandoned the idea that we can use the normative categories to establish moral conclusions, or at any rate we have pushed the problem back. For if the fact that someone ought to be treated in a certain way is supposed to follow from the fact she ought to be treated as a person, from what is it is supposed to follow that she ought to be treated as a person?

It is worth noting that for those who endorse a teleological conception of the world, this problem does not arise, because teleological principles, purporting to be at once factual and normative, themselves ground the bridge-claims; or at any rate, that is what they are supposed to do. This, I think, is how we should understand what is going on when religious thinkers say - as Aquinas does, for instance - that we may use the other animals as instruments because that is what they are for,${ }^{15}$ or what God gave them

\footnotetext{
${ }^{14}$ For Kant see G 4:387-88; G 4:406-11; see also MM 6:378. The locus classicus of the claim that you cannot derive an 'ought' from an 'is' is in Hume, A Treatise of Human Nature $\left(2^{\text {nd }}\right.$ edition ed. L. A. Selby-Bigge and P. H. Nidditch. Oxford: Clarendon Press, 1978), 3.1.1, 469-70. ${ }^{15}$ Aquinas, justifying the killing of animals, writes: 'There is no sin in using a thing for the purpose for which it is ... things, like the plants, which merely have life, are all alike for animals, and all animals are for man. Wherefore it is not unlawful if man use plants for the good of animals, and animals for the good of man ...' Summa Theologica, II, II, Question 64, Article 1.
} 
to us for. ${ }^{16}$ But those of us who reject the idea of a teleological conception of the world, or who, like Kant, think that we cannot have knowledge that the world is teleologically ordered, are left with the problem of how to understand the bridge-claims. They cannot provide a bridge between the normative conception and the factual conception of the world, if they must be either normative claims or factual claims themselves. But what alternative status can we find for these claims?

\section{The Kantian Solution}

Kant's solution, here as everywhere else, is to substitute the idea of rational practice for the idea of metaphysical (or teleological) knowledge. I will not try to defend that claim in its most sweeping form, but I will try to show how it works in the way Kant undertakes to establish the normative standing of humanity and the legitimacy of legal rights. I think this is a moment when we can see how radically different a Kantian view of the moral world is from that presented by most moral theories. In Kant's conception, the bridgeclaim linking rational beings to normative personhood is exactly that: it's a claim. That is to say, it is a claim in the practical sense: a demand, made by some rational being, either on himself, or on another rational being, or on the members of his community, or

\footnotetext{
${ }^{16}$ Aquinas continuing the above remarks quoted in note 15, writes: 'In fact this is in keeping with the commandment of God Himself: for it is written (Genesis 1:29-30): "Behold I have given you every herb ... and all trees ... to be your meat, and to all beasts of the earth": and again (Genesis 9:3): "Everything that moveth and liveth shall be meat to you." Summa Theologica, Question 64, Article 1.
} 
on the community of rational beings at large. That, after all, is what it means to believe, as Kant does, that ethics is a matter of making laws - willing universal maxims for ourselves and each other. It means that ethics is grounded not in some set of moral facts that we know about and apply, but in something that we $d o$. We make laws for ourselves and each other, and in so doing, we claim the standing or authority to make them.

The philosophical worry about this kind of theory is of course that it will render obligation arbitrary or contingent. After all, if legislating moral laws is supposed to be something that we $d o$, you might wonder what happens if we simply do not legislate moral laws, or if we legislate different ones than the ones we are familiar with? Kant's answer to this worry is to try to ground the story in an act that we must do, or in a claim that we must make, in virtue of our rationality. ${ }^{17}$ In order to act rationally, the argument goes, we must treat ourselves and demand that others treat us as moral and legal persons.

Before I can say why Kant thinks we must do this, I must fill in a little background. We can begin the story from one of the more startling things Kant says about human beings and the other animals. I have already quoted part of it. In Anthropology from a Pragmatic Point of View, Kant says:

The fact that man can have the idea 'I' raises him infinitely above all the other beings living on earth. By this he is a person; and by virtue of the unity of his consciousness, through all the changes he may undergo, he is one and the same person - that is, a being altogether different in rank and

\footnotetext{
${ }^{17}$ Or rather, we almost cannot help but do it. See my discussion of normative skepticism in The Sources of Normativity (Cambridge: Cambridge University Press, 1996), §§4.4.2, 161-4.
} 
dignity from things, such as irrational animals, which we can dispose of as we please. (ANTH 8:127)

In the Critique of Pure Reason, Kant tells us that the importance of the idea 'I' rests in the fact that we must be able to attach an 'I think' to all of our thoughts (C1 B 131-132). As I have argued elsewhere - although Kant himself never quite says this - a similar point holds for actions, to which we must be able to attach an 'I do' or an 'I will' (in the volitional rather than the predictive sense of 'will'). ${ }^{18}$

A general way of describing the Kantian project is to say that he argues that this in itself imposes certain limitations on what we can rationally think or do. His view is that the demands of rationality arise from the kind of self-consciousness that requires us to think of ourselves as the authors of our own thoughts, beliefs, and actions. This makes us persons in Locke's sense because we must take responsibility for the things that we think and do. Not every perception that tempts me to believe something leads to a belief I could legitimately attribute to myself, at least not considering myself as the subject of a conception of the world with the status of knowledge. And not every desire that tempts me to do something leads to an action that I could legitimately attribute to myself as the subject of a will, that is, as the cause - the first cause - of certain effects in the world. If I were going to try to tell the whole Kantian story from the ground up, this would be the place where the idea of making a claim would first come in. A self-conscious being, I would say, is one who must lay claim to his beliefs and actions, and make them his own,

\footnotetext{
${ }^{18}$ See my 'Self-Constitution in the Ethics of Plato and Kant' (in The Constitution of Agency, Oxford: Oxford University Press, 2008), 124.
} 
and who therefore must conform to whatever conditions are necessary to make that possible. $^{19}$

Obviously I'm not going to try to tell the whole Kantian story from the ground up in this paper. Instead I will just say a brief word about why, according to this account, we must make normative claims at all, and then turn to the discussion of the two particular claims that Kant thinks are required for rational action.

I have already said that the kind of self-consciousness that Kant thinks gives rise to the demands of rationality requires us to claim our thoughts and actions as our own. One thing that is necessary in order to do that is that we endorse the grounds of our beliefs and actions, where by 'the grounds' of our beliefs and actions I mean the contents of the mental representations that would directly cause our beliefs and actions if we did not have this form of self-consciousness. I cannot claim an action as my own if it is caused by the operation of a desire or an incentive whose influence I would reject if I were aware of it. ${ }^{20}$ As human beings, we are aware that we perceive certain things, want certain things, fear certain things, and we are also aware that we are tempted to believe and act on the basis of the contents of these attitudes. That means that we face a problem that the other animals presumably do not face: we have to decide whether to believe and act as our perceptions and desires suggest. How we make those decisions is a long story,

\footnotetext{
${ }^{19}$ In the language of my book Self-Constitution (Oxford: Oxford University Press, 2009), she must constitute herself as the author of her actions.

20 'Incentive' here translates Kant's own term 'triebfeder.' As I understand it, it refers to whatever it is about an object or state of affairs that causes you to desire or be averse to it.
} 
but when we have made them, and arrived at an answer, then we say that what we have is a 'reason.' A reason is a ground of belief or action whose influence you can endorse. Reasons are therefore the solution to a problem that is posed to us by our selfconsciousness. Self-consciousness forces us to act for reasons. That is why we must make normative claims.

I know that is abstract, but I think it will be clearer when we look at some concrete cases. So I now turn to Kant's account of the two normative claims that most concern us here: the claims to moral and legal personhood. My reconstruction of Kant's arguments cannot be complete, but I will describe the two central arguments in Kant's account of why a rational being must lay claim to the status of moral and legal personhood in order to act rationally at all. That is what I think Kant intended to show. I will also argue that in both cases, Kant's account suggests that we must lay claim to another, more basic form of normative standing as well.

\section{The Argument for the Formula of Humanity}

In order to understand why Kant thinks we must claim moral personhood, we must return to his argument for the Formula of Humanity, which, as I understand it, it goes like this. ${ }^{21}$ Because we are rational, we cannot decide to pursue an end unless we take it to be good that is, worth aiming at. Importantly, Kant takes the judgment that an end is good to

\footnotetext{
${ }^{21}$ I first made a version of this argument in 'Kant's Formula of Humanity' (in Creating the Kingdom of Ends. New York: Cambridge University Press, 1996).
} 
imply that there is reason for any rational being to promote it. As he says in the Critique of Practical Reason:

What we are to call good must be an object of the faculty of desire in the judgment of every reasonable human being, and evil an object of aversion in the eyes of everyone ... (C2 5:61)

What he means is not that everyone must want the same things that I do for themselves, but rather, that if my caring about an end gives me a genuine reason for trying to make sure that I achieve it, then everyone else has a reason, although of course not necessarily an overriding one, to try to make sure that I achieve it as well.

Obviously, that part of the story - the claim that my choice, if its object is genuinely good, has normative implications for everyone and not just for me - needs some further philosophical defense. If Kant assumed that whenever I make a choice I make a law that claims to bind everyone, he would simply be assuming that we claim the status of moral personhood whenever we make a choice. He would not be explaining why we must make that claim. So Kant must be able to give us some other reason why we must regard our choices as having this kind of interpersonal normative force insofar as they are rational.

Recall Kant's emphasis, in the passage from the Anthropology, on the selfconscious subject being the same person over time 'through all the changes he may undergo.' Here is how that matters to what can count as a reason. If I am to take something as a reason either to believe or to act, even knowing that my perspective on the 
world is always changing, I must also think it is a reason from perspectives other than the one that I occupy right now. We can argue that this is true regardless of whether the change in perspective is a change in perceptual experience resulting from, say, looking at an object from another angle, or a change in what we might call 'motivational perspective' resulting from the ever-shifting configuration of one's desires and fears. If I am to believe that a perceptual experience gives me knowledge of the world, I must believe that my other perceptual experiences will be consistent with what it tells me. And this amounts to the same thing as believing that other people's perceptual experiences will, under the right conditions, be consistent with it as well. The parallel point about action can most easily be seen if we keep in mind that carrying out an action takes time. ${ }^{22}$ If I am to will an end, that is to commit myself to bringing it about, I must be able to commit myself to pursuing it at a later moment when my general configuration of motives and desires may be different than it is just now. That amounts to thinking that it should appear as worthy of pursuit from any motivational point of view. (I'll make this clearer in an example shortly.) Call that being "absolutely" valuable.

Now many philosophers would conclude that this means that we can only rationally pursue an end if we think it is in fact intrinsically, and therefore absolutely, valuable. But this is where Kant reverses the argument, or rather where he puts the idea

\footnotetext{
${ }^{22}$ An emphasis on the fact that action takes time makes it easiest to see the point, but the point does not really depend on that fact. What matters is the availability of other perspectives in which I must suppose that my commitment would remain intact. See Self-Constitution (above (n. 19)) $\$ 4.5 .3,78-79$.
} 
of making a claim in place of the non-existent metaphysical insight. Instead of arguing that our ends must be intrinsically valuable, he argues that we can rationally pursue an end only if we are able to demand that it be treated as having absolute value - as if it had intrinsic value, one might say. And that amounts to saying that we are able to make a choice only by claiming the standing of moral personhood in Kant's sense of moral personhood - the right to make a law for others so long as those others may reasonably be asked to conform to it.

This reversal occurs because, as Kant observes, the ends that we choose are simply the objects of our inclinations, and the objects of our inclinations are not, considered just as such, absolutely or intrinsically valuable. As he puts it:

The ends that a rational being proposes at his discretion as effects of his actions ... are all only relative; for only their ... relation to a specially constituted faculty of desire gives them their worth ... (G 4:428) The objects of your own inclinations are only - or rather at most - relatively good, that is, good for you, that is, or good from your own point of view. ${ }^{23}$ As Kant thinks of it, they are, usually, things that you like and that you think would make you happy. Now it does not generally follow from the fact that something is good for someone in particular that it is good absolutely, in the sense that anyone has reason to promote it. If we pursue an end only if we take it to be good absolutely, then we do not pursue the objects of our

\footnotetext{
${ }^{23}$ I say, 'or at most' because the connection of inclination to what is good for us is defeasible; we might desire things that are bad for us, or - in Kant's conception of the matter - that are inconsistent with our happiness, and that are not rational to choose on that ground.
} 
inclinations merely because we think those objects are good for us. And yet we $d o$ pursue the objects of our inclinations, and we often expect others to help us in small ways, or at least not to interfere without some important reason for doing so. That suggests that we take it to be absolutely good that we should act as we choose and get the things that we think are good for us. So why do we do that?

Kant's answer is:

... rational nature exists as an end in itself. The human being necessarily represents his own existence this way... (G 4:429)

We 'represent' ourselves as ends in ourselves in the sense that we claim the status of absolute goodness for the things that are good for us. We claim that they are good just because they are good for us. I do not think that we should understand Kant as saying that we make an epistemological claim. I think he means that we make a kind of practical demand to be treated as beings whose good is an absolute good. It is as if whenever you make a choice, you said, 'I take the things that are important to me to be important, period, important absolutely, because I take myself to be important.' So a claim to a certain normative standing is built right into the nature of rational choice. And this claim must be made by anyone who has the descriptive qualifications for being a person - that is, anyone who, as a rational being, must choose only those ends that he takes to be absolutely good.

The bridge-claim linking rationality in the factual sense of self-consciousness to moral personhood is therefore a claim that we make - a demand that we make on 
ourselves and others. It is demand that we must make if we are to be able to view our choices as rational at all.

\section{Two Kinds of Normative Standing}

I believe that this argument has an additional implication, one that Kant didn't see. Obviously, it is only rational beings, in the descriptive sense, who need to claim a normative standing in order to act. But it does not follow that your claim to normative standing is made only on behalf of yourself considered as a rational being. The content of the claim is not automatically given by the fact that it is rational beings who make it. This becomes clear when we realize that there are two different senses in which, to put it in Kant's language, we 'represent ourselves' as ends in ourselves when we make choices. We represent ourselves as ends in ourselves insofar as we take the things that are good for us or from our point of view to be good absolutely, and we represent ourselves as ends in ourselves insofar as we take our choices to have the status of laws for others. The two ideas are very close, for to demand that an end be treated as absolutely good is just to demand that everyone treat it as giving them reasons, and in that sense to make a law for others. But there is still a difference, which shows up when we consider how these claims operate on ourselves as well as on others.

Suppose I choose to pursue some ordinary object of inclination, something that I want. In making this choice I make a demand on others. They should respect my autonomy, my status as a legislator in the Kingdom of Ends, by respecting my choice. 
They should not interfere with my acting as I choose, and, many other things equal, they should help me to promote my end if I am in need. But all of those restrictions operate, as it were, after the choice is made. And if Kant is right - if insofar as I am rational, I must choose something absolutely good, and yet the objects of my desires are only relatively good - then I also claim to be an end in myself simply by taking the objects of my desires to be absolutely good. When I act on the thought that 'what matters to me matters absolutely' I make a claim that is addressed in the first instance to myself.

This demand cannot be understood as a demand that my autonomy should be respected, that is, that I should respect my own standing as a lawmaker. The natural way to understand the idea that I respect my own autonomy is to suppose that I conform to a law simply because I myself have made it. Kant certainly does think that whenever I make a choice I make a kind of law for myself, as well as for other people, and the idea is not without content. In fact, it is the essential difference between choosing or willing something and merely wanting it. Wanting something, which is just a passive state, does not include a commitment to continuing to want it, but willing something, which is an active state, does include a commitment to continuing to will it, when everything else is equal.

For example, if I choose (or 'will', in Kant's language) to grow vegetables in my garden, knowing that this will require me to weed it on a regular basis, then I commit myself to weeding my garden at certain intervals in the future even should it happen that I do not feel like doing so. This is not to say that I decide that I will weed my garden no 
matter what - though the heavens fall, as it were. But it is to say that when I take something as the object of my will or choice, it follows that any good reason I have for abandoning this object must come from other laws that I have made or other commitments that I have undertaken or have decided to undertake, and not merely from a change in my desires. Having willed to grow vegetables in my garden, I can decide not to weed it if I need to rush to the bedside of an ailing friend, for instance. But I have not really decided, or willed, to grow vegetables in my garden if I leave it open that I will not weed my garden if I just do not happen to feel like it. For if all that I have decided when I decide I will keep my garden weeded is that I will weed it if I do happen to feel like it when the time comes, then I have not actually decided anything at all. ${ }^{24}$ So when I choose to grow vegetables as my end, I bind my future self to a project of regular weeding by a law that is not conditional on my future self's desires. In that sense, I have legislated a categorical imperative for her. But my future self in turn also binds me, for it is essential that if she is going to do the necessary weeding, I must now buy some pads to protect her knees, and the tools for her to weed with - and I must also do that whether I feel like it or not. In this simple sense, whenever I make a choice, I impose obligations on myself - I create reasons for myself. ${ }^{25}$ When I act on those reasons, you could say that I am respecting my own autonomy, by obeying the law that I myself have made.

\footnotetext{
${ }^{24}$ See Self-Constitution (above (n.19)), $§ 4.5$ for a fuller version of this argument.

${ }^{25}$ I hope this will give the reader a sense of what I had in mind earlier when I said that when we legislate a reason we must be able to suppose that it will still be a reason from various points of view.
} 
But my own original decision to choose or will some desired end is not motivated by respect for my own autonomy in that sense. I cannot respect my own choice or do what is necessary to carry it out until after I have made that choice. So the sense in which I 'represent myself' as an end in itself when I make the original choice is not captured by the idea that I respect my own autonomy, in the sense of taking my choice to be a law. Respect for my autonomy does not explain the content of my choice. When I make the original choice, I have no other ground for taking my end to be absolutely good, than that it is good for me. That's good for me, I say, and therefore it is good. This suggests that the pertinent fact about me - the ground on which I claim normative standing - is simply that I am the sort of being for whom, or from whose point of view, things can be good or bad.

Of course, someone might insist that I respect my own autonomy in a different sense: not in the sense that I treat a choice of my own as a law, but in the sense that I claim that what is good for autonomous rational beings, and only for autonomous rational beings, is to be treated as good absolutely. But that conclusion is not driven by the argument: there is no reason to think that because it is only autonomous rational beings who must make the normative claim, the normative claim is only about, or rather made on behalf of, autonomous rational beings. Notice, too, that many of the things that I take to be good for me are not good for me merely insofar as I am an autonomous rational being. Food, sex, comfort, freedom from pain and fear, are all things that are good for me insofar as I am an animate and sentient being. So it is more natural to think that the 
normative claim involved in rational choice is that the things that are good for beings for whom things can be good or bad are to be treated as good or bad absolutely.

We might put the point this way. As rational beings, we need to justify our actions, to think there are reasons for them. That requires us to suppose that some ends are worth pursuing - they are absolutely good. Without metaphysical insight into a realm of intrinsic values, all we have to go on is that some things are certainly good or bad for us. ${ }^{26}$ That then is the starting point from which we build up our system of values - we take those things to be good or bad absolutely, we claim the authority to legislate that they are so - and in doing that we are taking ourselves to be ends in ourselves. But we are not the only beings for whom things can be good or bad; the other animals are no different from us in that respect. So it seems natural to suppose we make this claim on behalf of our animal nature: not as autonomous beings whose choices must respected, but simply as beings for whom things can be good or bad.

\section{The Postulate of Practical Reason with Regard to Rights}

I now turn to Kant's account of legal rights. Even more explicitly than the argument for the Formula of Humanity, Kant's account why we have rights is a story about why we

\footnotetext{
${ }^{26}$ The Kantian argument here may be strengthened if we suppose that, in general, things must be good-for someone before they can be good, and that, therefore, everything that is good must be good-for someone. I have made a case for these theses in two papers, 'The Relational Nature of the Good,' (in Oxford Studies in Metaethics, Volume 8, ed. Russ Shafer-Landau. Oxford: Oxford University Press, 2013) and 'On Having a Good,' (forthcoming in Philosophy, the Journal of the Royal Institute of Philosophy).
} 
must be able to claim rights as against one another. The general story goes like this: Without the institution of rights, Kant thinks, we cannot free our relationships from the unilateral domination of some individuals by others. The problem is not, or not merely, that the strong are likely to impose their will on the weak. Even if the strong were scrupulous about not interfering with the possessions and actions of the weak, still, without rights, the weak would be able to act as they choose only on the sufferance of the strong (MM 6:312) - they would be subject to the will of the strong. Since Kant defines freedom as independence from being constrained by the will of others (MM 6:237), this means that he thinks freedom cannot exist in the state of nature. Until the institution of actual mechanisms for the coercive enforcement of rights, people cannot be free. And since Kant also supposes that every human being has an innate right to freedom (MM 6:237), Kant thinks it is a duty, and not just a convenience, to introduce a political state in which every human being's rights will be upheld (MM 6:307-8).

A full defense of this account in my terms would require explaining why the thesis that everyone has an innate right to freedom is best understood not as a metaphysical claim, but in terms of the idea that each of us must claim a right to freedom in order to act rationally. I cannot provide that full defense here, but will try to illustrate the idea by explaining why we must claim property rights.

Like others in the social contract tradition, Kant envisions a state of nature in which people lay claim to parts of the commons for their own private use. If it were not possible to claim objects as our own, Kant argues, we could not use them without being 
subject to the will of others, and therefore could not effectively use them to pursue our projects at all. I cannot effectively grow wheat on my land if you might move in at any time and plant beans there, and I cannot do so freely if the only way I can do it is to get your permission. In order to make free use of the land I must be able to claim a right to it. A piece of property is therefore a kind of extension of one's freedom. So to deny the possibility of claiming things in this way would be to place an arbitrary restriction on freedom (MM 6:246). Therefore we must concede that such claims - claims of property right - are possible. Kant calls this the Postulate of Practical Reason with Regard to Rights (MM 6:246).

Now a legal right is an authorization to use coercion. To say that you have a legal right to some piece of property is therefore to say that if someone attempts to use it without your permission, you may legitimately use force to prevent him from doing so. But coercion is legitimate only when it is consistent with freedom: rights are coercively enforceable only because they are essential to freedom. So the legitimacy of the use of coercion to defend a possession depends upon the consistency of that use of coercion with the freedom of everyone else (just as the moral legitimacy of your choice depends on its consistency with the autonomy of everyone else). A use of coercion is consistent with the freedom of everyone only if it is consistent with a universal agreement - a General Will, as Kant calls it, borrowing the idea from Rousseau - that the thing whose possession you are defending should be reserved to your use and control. In other words, 
your defense of your possession is legitimate only if a law made by the General Will says that the thing is to be your own.

What this means is that in the case of original acquisition - when you claim a right in the state of nature, you are in effect claiming to act in the name of the General Will, and so with the force of law. Even if political society does not exist yet, you are claiming to act in its name. In other words, a claim of the right to legislate for everyone, so long as your legislation is consistent with the freedom of everyone else, is built into the very structure of original acquisition. A claim to legal personhood is built directly into our use of an object as means to our end. This exactly mirrors the way a claim of the right to moral personhood is built into the very structure of rationally choosing to pursue the end itself. To say 'this is mine,' like to say 'this is good,' is to lay down the law for everyone, and makes a claim to your standing to do that.

Notice what happens when we put these two arguments together. In order to act rationally, you must choose an end, and you must pursue it using means. The argument for the Formula of Humanity shows us why a claim to moral personhood is involved in the choice of an end, and the argument for the Postulate of Practical Reason with Regard to Rights shows us why a claim to legal personhood is involved in the use of means. In order to act rationally, then, we must lay claim to both moral and legal personhood. 


\section{The Right to be Where You Are}

When we looked more closely at the decision to choose an end, we saw that there were two claims at work: a claim on both others and yourself that your choice should be respected, and a claim primarily on yourself that what is good for you should be treated as good absolutely. When we look more closely at the context of original acquisition, we again see that there is a double claim. In order to bring this out, let me first ask a question. What is there in the argument as I have described it so far that gives human beings the right to claim property in the other animals, or rather, what in general determines which things can count as property?

In the traditional doctrines of rights developed in the seventeenth and eighteenth centuries, especially in the theory of Locke, it is perfectly clear what makes it possible for people to claim property in the other animals. It is a view, derived from Genesis, to the effect that God gave the world and everything that is in it to humanity to hold in common. ${ }^{27}$ Like Locke, Kant insists on the essential role of this idea in his theory. He tells us that:

The real definition of a right would have to go like this: a right to a thing is a right to the private use of a thing of which $\mathrm{I}$ am in ... possession in common with all others. For this possession in common is the only condition under which it is possible for me to exclude every other possessor from the private use of a thing..., since, unless such a

\footnotetext{
${ }^{27}$ See the quotation from Aquinas in note 15.
} 
possession in common is assumed, it is inconceivable how I, who am not in possession of the thing, could still be wronged by others who are in possession of it and are using it (MM 6:261).

The passage is rather opaque, but here is what I think is going on. Kant's assumption is slightly less extravagant than an assumption of common ownership, because Kant distinguishes possession from ownership properly speaking, and it is common possession that he posits. When something is in my physical possession, anyone - that is, anyone who is not its rightful owner - who tries to use it without my permission wrongs me, because he has to use physical force or coercion to get it away from me. When I own something, someone who uses it without my permission wrongs me even when I am not in physical possession of it. It seems what the assumption of common possession amounts to is the assumption that no one has a prior right that would make it legitimate for him to exclude human beings from being in the world and using its resources, and therefore to exclude human beings from claiming it as property. But this common possession is taken to imply something normatively positive: that we $d o$ have the right to claim parts of the world as our own. The role of the assumption, whether of common ownership or of common possession, is to answer an obvious question: How could our agreement to divide the world up into objects of private property have any authority, if we had no right to the world in the first place?

Despite its explicitly religious formulation, the idea that God gave us the world in common captures something that goes right to the heart of the moral outlook, and that can 
be formulated in secular terms. It is the thought that others have just as good a claim on the resources of the world as we do, and that it behooves us to limit our own claims with that in mind. But the idea of the world as owned or possessed in common by humanity also represents the world, and everything in it, including the other animals, as one big piece of property. This is important, because it shows that the legal bifurcation is not based on some principled argument that proves that everything that is not a person is properly regarded as property. Instead, the traditional theory of rights simply starts from the unargued assumption that every thing in the world except people, including nonhuman animals, is a possible piece of property.

But what is the status of the assumption of common possession, or rather, of our participation in it? Can this assumption be reconfigured as a claim to normative standing that we must make in order to act rationally?

In this case, Kant seems pretty explicitly to claim that it can. He says: All human beings are originally (i.e. prior to any act of choice that establishes a right) in a possession of land that is in conformity with right, that is, they have a right to be wherever nature or chance (apart from their will) has placed them.... The possession by all human beings on the earth which precedes any act of theirs that would establish rights ... is an original possession in common..., the concept of which is not empirical ... Original possession is, rather, a practical rational concept which contains $a$ 
priori the principle in accordance with which alone people can use a place on the earth in accordance with principles of right. (MM 6:262)

Before there are any other rights, before we start dividing up the world for our purposes, each of us must claim a right to be where he or she is, to be wherever 'nature or chance' has placed us. And we must claim this in order to rightly use the resources of the earth.

What exactly is the content of this astonishing right? What does it mean to have a right to be where you are? The right to be where you are could be taken to be an aspect of your right to control over your own body, since it means that in the absence of prior claims to the ownership of land, no one has a right to force you to move on. A right to be where you are could be taken as a right not to be killed, since someone who is killed is forced to move on with a vengeance. Since a right to be on the earth, for Kant, goes with a right to use its resources for your support, that means that in the absence of prior claims, each of us has a right to take what he or she needs in order to live. In other words, we are thrown into the world, and having no choice but to live here, and to use the land and its resources in order to support and maintain ourselves, we claim that we have the right to do all of these things.

But the right to be where you are is not merely the right to claim a share of the earth's resources against its other possessors, so that you may pursue your projects unconstrained by the will of others. It is not merely the right to act unconstrained by the will of others. It is the right to act, period: the right to pursue your ends in the world in 
which you find yourself. When you act on the thought that you have the right to be here, you make a claim that is addressed in the first instance to yourself.

But we are not the only beings thrown into the world, who have no choice but to live here, and to use the land and its resources to get through life as best as we may. We are not the only agents. Of course it is true that rational beings are the only animals who must conceive of our situation in these normative and moral terms, and therefore the only beings who must claim that we have a right to act in the world in which we find ourselves. But again, the fact that it is rational beings who must make these claims does not show that the claims are made only on behalf of rational beings. And just as it is not merely out of respect for our own autonomy that we treat what is good for us as if it were good absolutely, so it is not merely in the name of our political liberty that we claim a right to regard ourselves as among the possessors of the earth. The right to be where you are reflects a normative standing we must claim for ourselves simply as beings who find themselves alive on the planet, faced with the tasks of living our lives in the only world that that we have. Just as our claim that our ends are absolutely good is based on nothing more than the fact that they are good for us, so our claim that we have the right to use the resources of the earth is based on nothing more than the fact that we are here and need to use them. If that is right, it suggests the other animals should share our standing as among the rightful possessors of the earth. 


\section{Conclusion}

The point of these arguments is not to suggest that non-human animals should have rights in the same sense that human beings do. On the contrary, I take it to be a virtue of these arguments, if they could be made to work, that they would preserve our special normative standing with respect to each other as free and autonomous beings, while still indicating that we also have a different kind of normative standing that we share with the other animals. I have not even begun to talk about the practical implications of the idea of this other sort of standing. In this paper, all I have tried to argue for is this: First, Kant's method shows us how to establish fundamental normative categories without appeal to supposed metaphysical insights, teleological hypotheses, or revelation. We can establish these categories by considering the normative demands that we must make on ourselves and each other in order to act rationally. And second, the moral claims that we must make on each other in order to choose our ends and so to act autonomously, and the legal claims we must make on each other in order to use means and so exercise that autonomy, presuppose another set of demands of an even more fundamental and primitive kind. They are normative demands that we make on ourselves in the name of our standing or value considered simply as beings for whom things can be good or bad, and who must pursue our good in the world in which we find ourselves. We assign ourselves a certain normative standing considered just as animals, faced with the problems that are common to all animal life. If that is right, there are three fundamental normative categories, not just two, and both our moral practices and our laws should be adjusted accordingly. 